\title{
CONTRIBUTION AND EFFECTIVENESS OF ACADEMIC SUPERVISION OF MADRASAH SUPERVISORS ON EDUCATION
}

\author{
Abd. Hakim \\ Kementerian Agama Bengkulu Tengah, Indonesia \\ Email: hakimmtpd@gmail.com
}

\begin{abstract}
Madrasah supervisors have a strategic role in the quality of education in Indonesia, so the contribution of school supervisors will have a significant effect on improving teacher performance, which will impact the implementation of learning in schools. This study aimed to determine the contribution and effectiveness of the academic supervision of madrasah supervisors on the quality of education and the factors that influence the contribution of madrasah supervisors to education. The research method used is literature study, using 2 data sources in the form of scientific journals and theses, searching for articles using the help of the Harzing's Publish or Perish application. The results showed that madrasah supervisors made a positive contribution to education in the form of mentoring teachers that would improve teacher performance. Factors affecting the contribution of school supervisors are the age and competence of madrasah supervisors. Academic supervision is effective if it is accompanied by good preparation by the madrasah supervisor, if the preparation is not maximal then academic supervision will be less effective. In the future, there needs to be a special education school for prospective school supervisors, so that competent school supervisors will be created.
\end{abstract}

Keywords: Contribution, effectiveness, academic supervision, madrasah supervisors, education

\begin{abstract}
Abstrak: Pengawas madrasah memiliki peran strategis terhadap mutu pendidikan di Indonesia, maka kontribusi pengawas sekolah akan berpengaruh besar terhadap peningkatan kinerja guru, yang pada akhirnya akan berdampak pada pelaksaan pembelajaran di sekolah. Tujuan penelitian ini adalah untuk mengetahui kontribusi dan efektivitas supervisi akademik pengawas madrasah terhadap mutu pendidikan, dan faktor yang mempengaruhi kontribusi pengawas madarasah terhadap pendidikan. Metode penelitian yang digunakan adalah studi pustaka, menggunakan 2 sumber data berupa jurnal ilmiah dan tesis, pencarian artikel menggunakan bantuan aplikasi Harzing's Publish or Perish. Hasil penelitian menunjukkan pengawas madrasah memberikan kontribusi positif terhadap pendidikan berupa pembimbingan terhadap guru yang akan meningkatkan kinerja guru. Faktor yang mempengaruhi kontribusi pengawas sekolah berupa usia dan kompetensi penagawas madrasah. Supervisi akademik efektif bila disertai dengan persiapan yang baik oleh pengawas madrasah, bila persiapan yang kurang maksimal maka supervisi akademik akan kurang efektif. Dimasa depan perlu ada sekolah pendidikan khusus bagi calon pengawas sekolah, sehingga akan terciptanya pengawas sekolah yang kompeten.
\end{abstract}

Kata Kunci: Kontribusi, efektivitas, supervisi akademik, pengawas madrasah, pendidikan

\section{INTRODUCTION}

Professional teachers cannot be separated from the guidance of supervisors. So one of the supervisor's duties to control madrasah management is carried out through supervision (Mudzakir, 2016). Supervision is all the help of school leaders, which is aimed at the development of leadership of teachers and other school personnel in achieving educational goals, in other words supervision is a coaching activity planned to assist teachers and other school employees in doing their work effectively (Bahri, 2014). Therefore, to carry out supervisory duties, supervisors must have qualifications and competencies superior to the capabilities and competencies of teachers and school principals. Supervision is one of the management functions concerning aspects of school 
management. Management science is needed so that the goals to be achieved can be achieved and be efficient and effective (Tunggal, 2002).

Supervision is an academic and administrative function that is classified as essential and vital. Supervision is also a managerial activity that is carried out after planning and organizing. Supervision is often interpreted by several meanings, controlling and directing (Asyari, 2011). Supervision is defined as the activity of testing, checking, verifying or even checking whether everything that happens is in accordance with the plan, the instructions issued, or the principles and principles that have been set or standardized. Supervision of public schools and madrasahs carried out by the Ministry of Education, and the Ministry of Religion is in the framework of fostering, developing, protecting, improving the quality and service of these schools and madrasahs. This supervision is more of an effort to provide guidance, encouragement, and protection for all concerned educational units that are expected to continuously improve the quality of education and its services (Ekawaty \& Ibrahim, 2018). Supervision is carried out on implementing education in public schools and madrasahs to obtain a comprehensive picture of school or madrasah management which includes educational and administrative aspects.

There are several factors that influence a teacher to carry out work, namely those originating from the teacher and outside the teacher himself. From within, such as motivation, skills, and education, those from outside such as salary, work climate, and others. Included that can contribute to teacher performance is the academic supervision of supervisors (Kartini \& Kristiawan, 2019). Academic supervision will control, direct, foster, and evaluate all teacher activities to achieve educational goals. The results of the evaluation of academic supervision will be used as input for teachers to improve the quality of education towards the best (Astuti, 2016). This study aimed to determine the contribution and effectiveness of the academic supervision of madrasah supervisors on the quality of education and the factors that influence the contribution of madrasah supervisors to education.

\section{LITERATURE REVIEW}

\section{Supervisors}

Supervisors are one of the education staff whose task is to provide supervision so that education personnel (teachers, school principals, other personnel in the school) can carry out their duties properly (Inggriani, 2019). Supervisors based on the decree of the State Minister for Administrative Reform, number 118/1996 and the Decree of the Minister of Religion, number 381 of 1999, stated that school or madrasah supervisors are civil servants are given full duties, responsibilities and authority by the authorized official to supervise the implementation of education in schools / madrasahs by carrying out assessment and guidance in terms of technical education and administration at pre-school, primary and secondary education (Fahmi, Nurliza, AR, \& Usman, 2018).

If examined based on government regulations and the Decree of the Minister for Administrative Reform and the Decree of the Minister of Religion, it can be said that the position of supervisors is very strategic and will affect the quality of education as a 
whole. Supervisors are functional and responsible for the learning, teaching, and guidance process in the school environment at various levels and types of instruction (Astarini, 2016). Its strategic function will improve the learning process and guidance carried out by teachers, school principals, and education personnel so that the education process will take place effectively, especially in the education environment of Elementary Schools or Madrasah Ibtidaiyah (Fahmi et al., 2018). The role of supervisors is vital or crucial because supervisors are at the forefront of ensuring the quality of education. Even though the teachers have been trained on the new curriculum and its development, they may experience difficulties and challenges in the field. How important the role of supervisors is because supervisors are expected to be able to provide input, advice and even increase the motivation, performance, and enthusiasm of teachers, so they do not give up and remain enthusiastic in trying to apply their ideas, knowledge, and skills in the classroom, including in this case is the courage to develop a curriculum in the school.

\section{Supervision}

Supervision is learning / academic is an effort to provide assistance planned by madrasah leaders, aimed at the development of teachers in carrying out their work effectively in achieving the goals of educational institutions given in the form of: encouragement, guidance and opportunities for the growth of skills and skills of teachers in carrying out their duties (Purwanto, 2005). Supervision activities are not just inspection activities but more than that, namely activities carried out to provide assistance and encouragement, because teachers need direct assistance from experts to improve the learning process (Sagala, 2005). The ultimate goal of supervision is to provide better service to all students. Of the various things that affect performance, the teacher's view of supervision by madrasah supervisors appears to be very fundamental and a very demanding factor in an educational institution or organization. These factors can have a good impact on teacher work.

\section{RESEARCH METHODOLOGY}

The research method used is a library research method, the purpose of library research is to find updated answers to the research objectives that have been made (Darmalaksana, 2020). The data sources of this research are scientific papers in the form of Scientific Journals and Theses. Searching research articles using the help of Harzing's Publish or Perish software this software is a tool that is widely used to find scientific articles. Search for scientific papers that are used as data sources using the google scholar database. The keywords used to search for articles were "madrasah supervisors" and contributions. The search for articles was carried out on May 1, 2021. The names of the journal sources of research data used can be seen in table 1 . The number of data sources used were: 6 scientific journals and three theses.

Table 1. List of research data sources journal names

\begin{tabular}{cl}
\hline No & \multicolumn{1}{c}{ Journal Name } \\
\hline 1 & Al-fikrah: Jurnal Manajemen Pendidikan \\
\hline 2 & Jurnal Al-Qayyimah \\
\hline
\end{tabular}




\begin{tabular}{ll}
\hline 3 & Ijtimaiyya: Jurnal Pengembangan Masyarakat Islam \\
\hline 4 & Tatar Pasundan : Jurnal Diklat Keagamaan \\
\hline 5 & Tsaqofah: Jurnal Agama dan Budaya \\
\hline 6 & Jurnal Administrasi Pendidikan \\
\hline
\end{tabular}

Table 2. Thesis list of research data sources

\begin{tabular}{|c|c|c|}
\hline NO & Thesis Title & Author \\
\hline 1 & $\begin{array}{l}\text { Efektivitas Pelaksanaan } \text { Supervisi Akademik Pengawas } \\
\text { Madrasah Di Madrasah Tsanawiyah Kabupaten Belitung } \\
\text { Tahun } 2011\end{array}$ & Sutina \\
\hline 2 & $\begin{array}{l}\text { Kontribusi Pengawas Pendidikan Agama Islam (PPAI) } \\
\text { dalam Pengembangan Kurikulum Tingkat Satuan Pendidikan } \\
\text { (KTSP) Madrasah Ibtidaiyah Swasta (MIS) di Kabupaten } \\
\text { Demak }\end{array}$ & Kholil \\
\hline 3 & $\begin{array}{l}\text { Kontribusi Supervisi Akademik Pengawas Madrasah Dan } \\
\text { Motivasi Kerja Guru Terhadap Kinerja Guru Di Min Se- } \\
\text { Kota Bandar Lampung }\end{array}$ & Faizaluddin \\
\hline
\end{tabular}

\section{FINDINGS AND DISCUSSION}

\section{The effectiveness of the academic supervision of madrasah supervisors on education}

Coaching the Head of Madrasah and Supervisors on the professional competence of teachers through KKG activities that have the usefulness, personal relationships of teachers into academic relationships, the development of the curriculum is quickly absorbed, there is a similar perception of curriculum implementation, improving the ability to prepare evaluation tools, the standardization of learning material levels and learning outcomes (Mustofa, 2008). So that competency on educational issues, educational psychology, learning methods and studies, and material mastery can be realized. The results of this study showed that based on the results of the analysis of the track obtained results; there is a positive influence of supervisory compliance on supervisory performance, supervisory competence to supervisory performance, supervisory compliance to the effectiveness of the implementation of supervisory programs, and supervisory performance to the effectiveness of the implementation of madrasah surveillance programs in JABODETABEK area (Supadi, 2018).

Field findings show varying levels of effectiveness, based on the analysis of the implementation of Madrasah supervisors 'academic supervision leading that the performance of Madrasah supervisors' academic supervision at MTsN is quite effective or good, even though the implementation of academic supervision does not have a fixed time or schedule. The implementation of the academic supervision of Madrasah supervisors at MTs At-Taqwa was not effective or good, and the performance of the academic supervision of Madrasah supervisors at MTs Daarul Aroofah was also less effective. Meanwhile, from the managerial aspect, the planning stage (input) runs less effectively at the implementation stage, academic supervision is also less effective, as 
well as the reporting or follow-up stage (output) is also less effective (Sutina, 2011). So overall, the effectiveness of the implementation of the academic supervision of Madrasah supervisors at MTs Belitung Regency is less effective or good. Based on the researcher's analysis of the implementation of the academic supervision of madrasah supervisors at Madrasah Tsanawiyah Belitung Regency, the researchers suggest that if the performance of academic supervision can be effective, it is better if madrasah supervisors are equipped with supervisory knowledge before going into the field, either through supervision training, or special Magister supervision education, so that madrasah supervisors now become supervisors of future madrasahs, supervisors who have higher knowledge than coaches, supervisors with a good work ethic, and supervisors who are visionaries for the coaches.

Based on these findings, it can be concluded that the academic supervision of madrasah supervisors will be effective if there is good preparation, if on the other hand the preparations are not maximal then academic supervision will be less effective. It is necessary to provide guidance for school supervisors, this is useful for increasing the ability of madrasah supervisors to supervise, along with the better competence of madrasah supervisors, it is hoped that the quality of academic supervision carried out will also increase. One of the determinants of the effectiveness of the academic supervision of school supervisors is the need to share perceptions between school supervisors and teachers, this will increase the effectiveness of the supervision carried out.

\section{Contribution of Madrasah Supervisors to education}

The contribution of madrasah supervisors at MTsN 1 Bone has been a form of mentoring carried out professionally by the supervisor and head of the madrasah. The guidance is carried out according to the needs of each teacher. The suggestion that is carried out is not without reason or need. This guidance is chosen, of course, to carry out supervision with a specific purpose (Septiana, 2019). The contribution of madrasah supervisors to teachers' performance in Islamic education subjects at MTsN 1 Bone analyzes various problems of Islamic education teachers. It helps Islamic education teachers solve issues about multiple activities in the learning process. Through this supervision, Islamic education teachers find ways to improve their performance and solve problems faced in administration, teaching and learning programs, and internal issues that sometimes become obstacles for Islamic education teachers themselves. Supervision in madrasah is carried out to develop better learning situations through teacher guidance and improve teachers' quality of learning performance. Furthermore, supervision is also defined as monitoring and evaluation activities to ensure that all educational activities in the education unit are carried out as planned. At the same time, it is also an activity to correct and correct any deviations that will interfere with achieving goals. For this reason, the contribution of supervisors is significant in helping solve learning problems experienced by teachers.

The Supervisor of Islamic Religious Education in Wedung Subdistrict, Demak Regency, as one of the PAI supervisors who apply intensive supervision and guidance, has contributed to academic supervision.Supervisor of Islamic Religious Education (Kholil, 2010). The result show that the Islamic Religious Education Supervisor has 
contributed to academic supervision. Madrasah Ibtidaiyah, which are in their target areas, deliver optimal performance on average; the learning process (educational) runs well according to the KTSP that has been made by madrasah. This is due to the young age of the Islamic Religious Education Supervisor, a supportive educational background, adequate work experience, high discipline, and can access learning resources from various sources, including information technology.

The results showed that (1) there was a significant contribution of supervisors' academic supervision to teachers' performance at the Bandar Lampung State Islamic Senior High School as evidenced by the Sig. work stress $\leq 0.05(0.000<0.05)$ (Faizaluddin, 2020). The contribution of supervisors' academic supervision to teacher performance is $19.3 \%$. (2) there is a significant contribution of teacher work motivation to the performance of the Bandar Lampung State Madrasah Ibtidaiyah teachers, as evidenced by the Sig value of work motivation obtained $\leq 0.05(0.004<0.05)$. In contrast, the contribution made is $18.1 \%$ (3). There is a significant contribution of academic supervision and teacher work motivation to the performance of the Bandar Lampung State Madrasah Ibtidaiyah teachers, as evidenced by a sig value of $0.000<0.05$, which means that Ho is rejected and (Ha is accepted). With a contribution value of 0.247 Adjusted R Square value is positive, the independent variables (supervisors' academic supervision and teacher work motivation) can explain the variance of the dependent variable by $24.7 \%$, and the remaining $75.3 \%$ is caused by other variables that are not in this research.

The supervision of madrasah supervisors has made a positive and significant contribution to teachers' performance at Madrasah Tsanawiyah (MTs) throughout Sungai Tarab District (Marita, 2016). Based on the research results, the supervision of madrasah supervisors is in the excellent category; this can be taken into consideration in determining the program for the Ministry of Religion in the procurement of subject supervisors. Suppose the number of madrasah supervisors has met the requirements and educational background according to the coached teachers. In that case, it will make a significant contribution to improving teacher performance in the madrasah. Qualified madrasah supervisors will be able to create madrasahs to achieve their goals without harming other parties. Supervisors must have the ability to direct and encourage teachers, guide them in carrying out their duties, seek the facilities needed by teachers for the learning process, and train teachers in carrying out their functions as educators and always providing advice. If the abilities of madrasah supervisors are not improved, the teacher's performance will not improve either. Improving the quality of madrasah supervisors can be done through education and training to increase their competence and influence education in madrasah. Expanding the work motivation of madrasah teachers can be done by providing rewards and punishments.

Based on the results of this study, it can be said that the quality of learning can be improved through increased leadership, teacher performance, and supervisor competence. As an element of leadership through his policy, the principal must provide maximum facilities to realize quality learning (Patimah, 2017). As the spearhead of the learning process, teachers must improve their performance. Education supervisors must have 
adequate competence in carrying out their primary duties and functions as academic supervisors and supervisors of academic units.

\section{Factors affecting the contribution of Madrasah supervisors to education}

The competency test of prospective supervisors has contributed to the development of managerial supervision instruments in functional training to form prospective madrasah supervisory positions held at BDK Bandung in 2015 (Sumarna, 2018). The magnitude of the contribution of the competency test to the development of managerial supervision instruments can be seen from the regression equation $\hat{Y}=49.77+0.26 \mathrm{X}$. From the regression equation, it can be concluded that every one-point increase in the competency test will contribute as much as 0.26 points to the development of the instrument-managerial supervision. In addition, the supervisor's competency test also has a relationship with the correlation coefficient $(r=0.247)$ with the development of administrative supervision instruments. For the result of subsequent research, it is necessary to pay attention to the following matters: 1. The story of managerial supervision instruments is essential in implementing the duties of madrasah supervisors. Therefore the quality of the instruments must be tested for validity and reliability through instrument testing or expert opinion. 2. There needs to be a follow-up study related to the training for the formation of prospective madrasah supervisory positions through the Post-Education and Training Evaluation activities to determine whether the instruments developed by the prospective madrasah supervisors are followed up in the supervision of the madrasah under the supervision.

The research results in this thesis obtained data that the Islamic Religious Education Supervisor has shown its contribution, namely the Islamic Religious Education Supervisor has conducted regular coaching, which is equipped with their respective instruments and is involved in the development of KTSP in Private Madrasah Ibtidaiyah. Still, the contribution is different. Islamic religious education supervisors, who are relatively young, will provide more guidance to madrasahs. Coming to madrasahs is also different between young supervisors and supervisors who are old or approaching their retirement (Kholil, 2010). The things that distinguish the size of the contribution of the Islamic Religious Education Superintendent include age, educational background, work experience, official duties outside the supervisor's responsibilities, the ability to extract information from various media, and the mindset of the purpose of supervision to Madrasah Ibtidaiyah. Based on the results of this study, it is hoped that the supervisors of Islamic Religious Education will continually improve their performance and competence, primarily academic and administrative or managerial competence. The supervisor of Islamic Religious Education is expected to change the paradigm and perspective of supervision, that education is dynamic, advanced, and constantly developing. Therefore, the Islamic Religious Education Supervisor must explore as much experience as possible, both studying, reading, and continuing education to a higher level and being diligent in accessing various media related to education and being proficient in mastering information technology. 


\section{CONCLUSIONS}

Academic supervision carried out by school supervisors effectively improves the quality of education. Still, the effectiveness of this academic supervision must be supported by good preparation by the school supervisor because if the practice is not maximal, the academic supervision carried out will be less effective. The contribution of school supervisors to education is positive. The gift of school supervisors in mentoring and coaching teachers and solving problems in madrasas will improve teacher performance. Factors that affect the performance of school supervisors during academic supervision are the competence of the school supervisor and the age of the school supervisor. Improving the competence of school supervisors should be a priority in the future to maintain and improve the quality of education in madrasah.

\section{REFERENCES}

Astarini, D. (2016). Meningkatkan Kemampuan Kepala Sekolah dalam Menyusun Program Supervisi Akademik melalui Pendampingan dan Supervisi Manajerial. Jurnal Manajemen Dan Supervisi Pendidikan, 1(1), 36-41. https://doi.org/10.17977/um025v1i12016p036

Astuti, S. (2016). Penerapan Supervisi Akademik Untuk Meningkatkan Kompetensi Guru Dalam Menyusun Administrasi Penilaian Di SD Laboratorium UKSW. Scholaria: Jurnal Pendidikan Dan Kebudayaan, 6(1), 117-126. https://doi.org/10.24246/j.scholaria.2016.v6.i1.p117-126

Asyari, M. (2011). Supervisi Akademik Pengawas Madrasah Tsanawiyah di Kabupaten Jepara (eprints.walisongo.ac.id).

Retrieved from http://eprints.walisongo.ac.id/344/

Bahri, S. (2014). Supervisi Akademik Dalam Peningkatan Profesionalisme Guru. Visipena Journal, 5(1), 100-112.

https://doi.org/10.46244/visipena.v5i1.236

Darmalaksana, W. (2020). Metode Penelitian Kualitatif Studi Pustaka dan Studi Lapangan. Pre-Print Digital Library UIN Sunan Gunung Djati Bandung, 1-6. Retrieved from http://digilib.uinsgd.ac.id/32855/1/Metode Penelitian Kualitatif.pdf

Ekawaty, A. E., \& Ibrahim, S. (2018). Pelaksanaan Supervisi Manajerial Oleh Pengawas Sekolah Dalam Meningkatkan Mutu Pendidikan Di SDN 3 Percontohan Peusangan Kabupaten Bireuen. Jurnal Administrasi Pendidikan: Program Pascasarjana Unsyiah, 6(3), 183-191.

Retrieved from http://www.jurnal.unsyiah.ac.id/JAP/article/view/13137

Fahmi, C. N., Nurliza, E., AR, M., \& Usman, N. (2018). Pelaksanaan Supervisi Akademik Dalam Meningkatkan Kompetensi Guru Sekolah Dasar. Jurnal Serambi Ilmu, 30(2), 104-119. https://doi.org/10.32672/si.v30i2.755

Faizaluddin, F. (2020). Kontribusi Supervisi Akademik Pengawas Madrasah Dan Motivasi Kerja Guru Terhadap Kinerja Guru Di Min Se-Kota Bandar Lampung. Retrieved from http://repository.radenintan.ac.id/9620/

Inggriani, S. (2019). Pengaruh Supervisi Pengawas Di Sekolah Dan Gaya Kepemimpinan Kepala Sekolah Terhadap Peningkatan Kinerja Guru SMP. Jurnal Lentera Pendidikan Pusat Penelitian LPPM UM METRO, 1(2), 1-6. https://doi.org/10.31227/osf.io/5fa39

Kartini, D., \& Kristiawan, M. (2019). Pengaruh Tunjangan Profesi dan Motivasi Kerja 
Terhadap Kinerja Guru. Kelola: Jurnal Manajemen Pendidikan, 6(1), 25-33. https://doi.org/10.24246/j.jk.2019.v6.i1.p25-33

Kholil, K. (2010). Kontribusi Pengawas Pendidikan Agama Islam (PPAI) dalam Pengembangan Kurikulum Tingkat Satuan Pendidikan (KTSP)Madrasah Ibtidaiyah Swasta (MIS) di Kabupaten Demak (eprints.walisongo.ac.id).

Retrieved from http://eprints.walisongo.ac.id/97/

Marita, H. (2016). Kontribusi Supervisi Pengawas Madrasah Dan Motivasi Kerja Guru Terhadap Kinerja Guru Mts Se Kecamatan Sungai Tarab. Al-Fikrah: Jurnal Manajemen Pendidikan, 1(2), 141-151. https://doi.org/10.31958/jaf.v1i2.359

Mudzakir, D. (2016). Implementasi Supervisi Manajerial Dan Akademik Pengawas Dalam Meningkatkan Kinerja Guru Pendidikan Agama Islam Madrasah Ibtidayah. DIDKATIKA Jurnal Ilmiah Pendidikan., 10(2), 33-47.

Retrieved from http://www.jurnal.uinbanten.ac.id/index.php/studiadidaktika/article/view/81

Mustofa, M. (2008). Efektifitas Pembinaan Kepala Madrasah Dan Pengawas Terhadap Kompetensi Profesional Guru Min Kabupaten Serang. Tsaqofah, 6(2), 208-217. Retrieved from http://103.20.188.221/index.php/tsaqofah/article/view/3514

Patimah, H. S. (2017). Madrasah Efektif: Kontribusi Kepemimpinan, Kinerja Guru dan Kompetensi Pengawas terhadap Mutu Pembelajaran di Madrasah Ibtidaiyah Swasta Kota Bandar Lampung. Ijtimaiyya: Jurnal Pengembangan Masyarakat Islam, 10(2), 387-400. https://doi.org/10.24042/ijpmi.v10i2.3298

Purwanto, M. N. (2005). Administrasi dan Supervisi Pendidikan. Bandung: PT Remaja Rosdakarya.

Sagala, S. (2005). Konsep dan Makna Pembelajaran. Bandung: CV Alfabeta.

Septiana, S. (2019). Kontribusi Pengawas Madrasah terhadap Kinerja Guru Pendidikan Agama Islam dalam Meningkatkan Kualitas Belajar di MTSN 1 Bone. $A L-$ QAYYIMAH: Jurnal Pendidikan Islam, 2(1), 113-124.

Retrieved from

https://www.jurnal.iainbone.ac.id/index.php/alqayyimah/article/view/602

Sumarna, N. U. (2018). Kontribusi Uji Kompetensi Calon Pengawas Madrasah Terhadap Pengembangan Instrumen Supervisi Manajerial. Tatar Pasundan: Jurnal Diklat Keagamaan, 12(32), 11-22. https://doi.org/10.38075/tp.v12i32.50

Supadi, S. (2018). Efektivitas Program Kepengawasan Madrasah Berdasarkan Kepatuhan Dan Kompetensi Pengawas. Jurnal Administrasi Pendidikan, 25(1), 13-20. https://doi.org/10.17509/jap.v25i1.11567

Sutina, S. (2011). Efektivitas Pelaksanaan Supervisi Akademik Pengawas Madrasah Di Madrasah Tsanawiyah Kabupaten Belitung Tahun 2011 (repository.radenfatah.ac.id).

Retrieved from http://repository.radenfatah.ac.id/id/eprint/6497

Tunggal, A. W. (2002). Manajemen Suatu Pengantar. Jakarta: PT. Rineka Cipta. 